\title{
Does Microbial Diversity of Cave Ecosystems Differ from Outside? The Case of the Azé Show Cave (France)
}

\section{Badr Alaoui-Sosse}

UMR 6249 CNRS/Université Bourgogne Franche

Shinji Ozaki

UMR 6249 CNRS/Université Bourgogne Franche

Lionel Barriquand

Université Savoie-Mont-Blanc

Daniele De Luca

University of Naples Federico II

\section{Paola Cennamo}

University of Naples Suor Orsola Benincasa

Benoit Vallot

UMR 6249 CNRS/Université Bourgogne Franche

Laurence Alaoui-Sosse

UMR 6249 CNRS/Université Bourgogne Franche

\section{Pascale Bourgeade}

UMR 6249 CNRS/Université Bourgogne Franche

\section{Faisl Bousta}

Laboratoire de Recherche des Monuments Historiques (LRMH)

\section{Lotfi Aleya}

UMR 6249 CNRS/Université Bourgogne Franche-Comté UsC INRA

Stéphane Pfendler ( $\sim$ stephane.pfendler@univ-fcomte.fr)

Laboratoire Chrono Environnement https://orcid.org/0000-0002-1571-2559

\section{Research Article}

Keywords: Caves, Conservation, Biodiversity, Microorganism communities, Metabarcoding

Posted Date: May 5th, 2021

DOI: https://doi.org/10.21203/rs.3.rs-471958/v1 
License: (c) (i) This work is licensed under a Creative Commons Attribution 4.0 International License. Read Full License 


\section{Abstract}

In recent decades, the Azé cave has begun to suffer from microorganism proliferation due to artificial lighting installations for touristic activity. The present work aims at understanding the origin of the Lampenflora and bacterial community populating inside the cave. We performed high throughput sequencing of the communities populating the outside, the entrance and the inside of the Azé cave. Our results indicated that $68.2-74.5 \%$ of the phototrophic community was represented by Eukaryotes, and 25.5 to $31.8 \%$ by cyanobacteria regardless of the sampled area. We observed a decrease of bacterial and phototroph species richness from the outside to the bottom of the cave. The phototrophic communities were significantly different in term of specific OTU richness but not in term of composition. For photosynthetic organisms, only 4 OTU were specific to the inside of the cave, representing less than $0.1 \%$ of the total OTUs. On the contrary, more than 400 bacterial OTUs were specific to the inside of the cave. These metabarcoding-based findings in the Azé cave revealed a complex community structure that is similar but less diverse in comparison to the outside.

\section{Introduction}

Caves are oligotrophic ecosystems characterized by the absence or low light level, stable temperature and high humidity [1]. Despite low amounts of organic matter [2], Barton and Jurado (2007) [3] have estimated that $10^{6}$ microorganisms per gram of rock inhabit in these ecosystems. Microorganisms grow inside self-made anionic EPSs (Extracellular Polymeric Substances) [4], called biofilm, that has a threedimensional architecture [5]. Two types of biofilms may be easily distinguished in the caves. First, the photosynthetic biofilm mainly composed by cyanobacteria, micro-algae, diatoms and bacteria [6]. Then, the non-photosynthetic biofilms that are less studied and inhabited by bacteria such as Actinobacteria [7]. For their expansion on cave rock, all microorganisms require five growth conditions [8]. First, the bioreceptivity that has dissimilar levels depending on the type of substrata [9]. On this regard, Jones et al. (2017) [10] have reported that surface type significantly controlled 70 to $90 \%$ of the variance in phylogenetic diversity. Then, moisture, temperature and nutrients are essential for microorganism survival, growth, and expansion $[11,12,13]$. Finally, photosynthetic biofilms need a natural (usually at the cave entrance) or an artificial lighting source (mounted for the tourists) depending on their location in the cave [1].

Since several decades, the cave microbiome has been studied for several reasons [14] such as medical or pharmaceutical interests (e.g., research of antibiofilm compounds) [15] and cave preservation (e.g., Paleolithic drawings and rock paintings curation) $[16,17,18]$. These studies have been carried out using a large set of microorganism identification technics such as microscopic methods [19, 20], isolation and culture in laboratory [21], cloning followed by Sanger sequencing [22, 23, 24], amplified ribosomal DNA restriction analysis [25] or high throughput sequencing $[6,26,27,28]$. Results of these studies have demonstrated that cave microorganisms developing inside biofilms may be involved in speleogenesis processes. Indeed, it has been reported that the complex microbial communities are capable of reflecting in substantial rock alterations, involved in calcification processes [21, 29, 30, 31], formation of new 
structures [32], corrosion of the mineral surfaces [4] and cave expansion [1,33]. Thus, the biodeterioration process is of great concern to cave owners and managers who find themselves faced with a dual problem: the esthetic impact of biofilms $[34,35,36]$ and the biodeterioration $[31,37]$.

Despite phototrophic biofilms have been studied for several decades, studies comparing the microbial communities occurring inside and outside cave environments are very limited [38,39,40]. The differences between communities would provide a better understanding of the microorganism sources and thus about biofilm genesis inside the cave. Moreover, it will permit to know how much the communities differ. In the present work, we have analyzed the biofilm communities growing inside the Azé show cave through high-throughput sequencing and compared them with those growing outside the cave.

\section{Material And Methods \\ 2.1. Site description}

This study was carried out in one of the caves of Azé, which are located in the Monts du Mâconnais (Saône-et-Loire, Burgundy, France), on the edge of a tributary of the Saône river called the Mouge. The two main caves of Azé were dug in Middle Jurassic limestones (from the Aalenian to the Lower Bathonian), and are open into the cliff overlooking the valley, at the level of a small circus facing south [41]. The entrance of the prehistoric cave, the one we have sampled in this study, is located at $275 \mathrm{~m}$ above sea level. At 180 to $200 \mathrm{~m}$ of the entrance, a large area was unobstructed from the sediment during the winter 1976-1977, and many bear bones (160,000-year-old Ursus deningeroides) were discovered [42]. Several vestiges of the Lower and Upper Paleolithic, Bronze Age, Gallo-Roman period and Middle Age (including a wall), also remain in the cavity, and the caves are nowadays visited by 28,000 tourists each year [6].

\subsection{Environmental parameters}

Environmental conditions in the Azé cave have been monitored for several years (Table 1) showing two different seasonal regimes were measured. First, during the winter a convection loop is established and the $\mathrm{CO}_{2}$ level is then normal. Then, during the summer, the warm outside air blocks the cold air in the cave and the $\mathrm{CO}_{2}$ level can exceed 3.5\% in the deepest parts of the cave. The entrance zone undergoes strong temperature variations while in the terminal zone of the cave the temperature varies approximately between 11.5 and $12.0^{\circ} \mathrm{C}$. The entrance is highly influenced by the outside humidity, while the air is always saturated with humidity beyond $80 \mathrm{~m}$ from the entrance. 
Table 1

Annual variation of the moisture, temperature and $\mathrm{CO} 2$ concentration. The light intensity was monitored during the biofilm sampling day.

\begin{tabular}{|lllll|}
\hline Sampling sites & Moisture $(\%)$ & Temperature $\left({ }^{\circ} \mathrm{C}\right)$ & $\mathbf{C O}_{2}(\%)$ & Light intensity \\
\hline Entrance & 35,5 to $>98$ & $-1,5$ to 25,5 & 0,04 & 0,24 to 27,5 \\
\hline Rotonde & 35,5 to $>98$ & $-1,5$ to 25,5 & 0,04 & 17,7 \\
\hline Gour & 72 to $>98$ & 6 to 15,5 & 0,04 to 0,4 & 6,25 \\
\hline 14July & $>98 \%$ & 11,2 to 12,9 & 0,04 to 1 & 2,1 \\
\hline Bear & $>98 \%$ & 11,2 to 12,9 & 0,04 to 1,50 & 6,4 \\
\hline
\end{tabular}

\subsection{Light profile}

Natural light profile of the Azé cave was measured using the LiCOR Li250A light meter in April 2018. Photosynthetic Active Radiation (PAR) measurements were done at solar noon (at 2 pm) at 1.80-meterhigh, every one meter, in the 42 first meters of the cavity. Measurements were carried out until no more light was detected (PAR $=0 \mathrm{~mol} \mathrm{~m}^{-2} \mathrm{~s}^{-1}$ ). To avoid artificial lights pollution, cave illuminations were switched off.

As well as natural light, artificial light intensities were collected inside the show cave. The light meter detector was placed (i) on the phototrophic biofilms and (ii) at $2 \mathrm{~cm}$ from light source.

\subsection{Colorimetric measurement of biofilm}

The sampled biofilms differed according to their colors. For this reason, the biofilm colorimetric parameters were measured with a spectrophotometer (CM-600d KONICA MINOLTA, illuminant D65, SCI mode and $8 \mathrm{~mm}$ diameter target mask). Color measurements were analyzed according to the CIELAB color system. The $a^{*}$ scale is associated with changes in redness-greenness (positive $a^{*}$ is red and negative $a^{*}$ is green) [43].

\subsection{Quantum yield measurements}

In order to distinguish photosynthetic biofilms from non-photosynthetic biofilms, quantum yield measurements, corresponding to phototrophs metabolism, were carried out. Before each sampling, five measurements were taken on each biofilm, which were previously placed for $30 \mathrm{~min}$ in the dark. Quantum yield parameter (Fv/Fm) was monitored using the photosynthesis yield analyzer mini-PAM (WALZ, Germany) as follows:

$F V / F m=\phi P S I / / q P$

\subsection{Biofilm sampling}

The phototrophic biofilms were collected outside, at the entrance (first 27 meters) and inside the cave (from the 27 th meter to the bottom of the cave). Five samples were collected from the limestone rock 
(hereinafter referred as "Out_rock") and other five samples from the soil (called "Out_soil") outside the cave. Then, eight samples were taken at the entrance area ("Ent"), and twelve other samples from the end of the entrance to the bottom of the farthermost cave area ("Ins"): Rotonde ("rot"), Gour, North Gallery, "14 Juillet" room ("July"), and on a bear bone (bear room).

In accordance with the sequencing platform (Microsynth AG, Balgach, Switzerland), 100 to $200 \mathrm{mg}$ of fresh matter was taken from each biofilm sample. To avoid unwanted contamination, biofilms were directly scraped using 2-ml sterile tubes containing a buffer and balls for mechanical lysis, and subsequently kept on dry ice $\left(-78^{\circ} \mathrm{C}\right)$. Samples were then conserved by MicroSynth $A G$ at $-20^{\circ} \mathrm{C}$ until total DNA extraction.

\subsection{Molecular methods and sequencing}

For DNA extraction, PowerBiofilm DNA Isolation Kit was used by MicroSynth AG following the manufacturer's instructions (MoBio Laboratories, Inc., Carlsbad, CA, USA). The polymerase chain reaction (PCR) amplification followed a two-step PCR protocol using a state-of the-art high fidelity polymerase.

This two-step PCR was applied in order to increase reproducibility and to improve the production of highquality multiplex amplicon libraries. PCRs were performed with the primers p23SrV_f1, p23SrV_r1 [44, 45] and 16S $799 \mathrm{f} \mathrm{(5'} \mathrm{-AACMGGATTAGATACCCKG-} \mathrm{3')} \mathrm{and} \mathrm{16S} 1115 \mathrm{r}$ (5' -AGGGTTGCGCTCGTTG- 3'). For 23S region, we used the following PCR protocol: initial denaturation at $94^{\circ} \mathrm{C} / 2 \mathrm{~min}, 20$ cycles of $94^{\circ} \mathrm{C} / 20$ sec, $55^{\circ} \mathrm{C} / 30 \mathrm{sec}, 72^{\circ} \mathrm{C} / 30 \mathrm{sec}$ and final elongation $72^{\circ} \mathrm{C} / 5 \mathrm{~min}$. For $16 \mathrm{~S}$ primer, DNA was amplified as follows: initial denaturation at $95^{\circ} \mathrm{C} / 3 \mathrm{~min}, 20$ cycles of $98^{\circ} \mathrm{C} / 20 \mathrm{sec}, 64^{\circ} \mathrm{C} / 30 \mathrm{~min}, 72^{\circ} \mathrm{C} / 30 \mathrm{sec}$ and final elongation $72^{\circ} \mathrm{C} / 5 \mathrm{~min}$. PCR products were purified, quantified with fluorescence spectroscopy using Picogreen (Quant-iT ${ }^{T M}$ PicoGreen ${ }^{\text {TM }}$ dsDNA Assay Kit, Thermo Fisher) and then pooled in equimolar amounts. DNA sequencing was performed on one MiSeq run with 2x250v2 according to standard protocols (capacity per run: app. 10 million reads, Illumina passed filter data).

\subsection{Sequence data analysis}

Reads were assigned to each sample according to a unique barcode. Paired reads were assembled into contigs using the Mothur pipeline [48]. An in-silico PCR kept only reads containing the used forward and reverse primer. For $16 \mathrm{~S}$ generated sequences, the contigs were pre-clustered at $99 \%$ similarity, while $23 \mathrm{~S}$ sequences were dereplicated as unique sequences. Rare sequences, represented by less than 10 reads for $16 \mathrm{~S}$ and $23 \mathrm{~S}$ primers, were removed from the analysis. The $16 \mathrm{~S}$ and $23 \mathrm{~S}$ taxonomic assignments were performed using SSU and LSU SILVA database (v132), respectively. Operational taxonomic units (OTUs) were then constructed using the Needleman-Whunch distance and average neighbor clustering (UPGMA) at a distance of 0.03 , and 0.05 for $16 \mathrm{~S}$ and $23 \mathrm{~S}$ primer sequences, respectively. The number of reads per sample was calculated after a random sub-sampling of 10,000 reads. Nucleotide data were deposited in the GenBank database under the BioProject ID: PRJNA723481.

\subsection{Statistical analysis}


The relationship between the solar light intensity and the distance from the entrance was analyzed by the linear regression. The coefficient of determination $\left(R^{2}\right)$ was calculated if the relationship was significant ( $p$-value < 0.05) under ANOVA. OTU Richness, Simpson's diversity index, and Simpson's evenness at outside, entrance and inside were compared for both phototroph and bacterial communities, using the nonparametric Kruskal-Wallis test because of skewed distribution of OTUs. Community composition was separately analyzed for phototrophic and bacterial communities. An analysis of similarity (ANOSIM) test was performed on the non-metric multidimensional scaling (NMDs) analysis.

All statistical analyses were performed using R software version 4.0.2 (R Development Core Team, 2016). Kruskal-Wallis tests and multiple comparisons of samples were performed by the "kruskal" function from the "agricolae" package.

\section{Results}

\subsection{Natural and artificial light profiles}

Outside the cave, the light intensity reached $779 \mathrm{~m}^{-2} \mathrm{~s}^{-1}$ (data not shown), while inside the cave, the solar light decreased exponentially $\left(R^{2}=0.99\right)$ from the entrance (0th meter: $9.5 \mathrm{~mol} \mathrm{~m}^{-2} \mathrm{~s}^{-1}$ ) to the 37 th meter $\left(0 \mathrm{~mol} \mathrm{~m}^{-2} \mathrm{~s}^{-1}\right)\left(\mathrm{R}^{2}=0.99\right.$; Fig. 1a). The artificial light intensities (Fig. S1 a) have showed a disparity of radiations ( 137 to $5060 \mathrm{~mol} \mathrm{~m}^{-2} \mathrm{~s}^{-1}$ ) along the cave. Available light for the biofilms (Fig. 1b), that is presenting on Fig. S1b, showed $0.2,7.4$, and $27.5 \mathrm{~mol} \mathrm{~m}^{-2} \mathrm{~s}^{-1}$ as the minimum, the average, and the maximum light intensity, respectively. Finally, the distance between the lamps and biofilms varied between 0.23 to 5.06 meters (data not shown).

\subsection{Quantum yield and colorimetric measurements}

The data (Fig. S2) have showed that, whatever the light intensity or light sources (natural or artificial), the quantum yield efficiency of the sampled biofilms (Fig. $1 \mathrm{~b}$ ) was greater than 0.6 (average: Fv/Fm $=0.67$ ).

Our results showed that biofilms located in the first 60 meters of the cave (i.e., Rotonde and Entrance samples) have the lower green-red scale values (Fig. S3). In fact, the biofilms have exhibited negative values (average $=-4.17$ ) corresponding to green color and thus higher microorganism density. All the Gour, '14 Juillet' and Bear bone samples, located in the second half of the cave, have positive values (from 1.68 to 3.37 ), corresponding to lower green intensity and higher red intensity (limestone wall colour).

\subsection{Assessment of microbial communities 3.3.1. Taxonomic composition of biofilms}

The Fig. 2 shows the distribution of the photosynthetic organisms according to their sampling localization. Our results showed that eukaryotes were always the dominant taxon in comparison to cyanobacteria. Photosynthetic eukaryote (74\%) and cyanobacteria (26\%) proportions were similar 
between both inside and entrance biofilms, while outside biofilms were represented for $31 \%$ by cyanobacteria.

The Chlorophyta phylum was prevailing in biofilms regardless the localization ( $57.6 \%$ inside, $90.4 \%$ at the entrance and $66.7 \%$ outside). The less represented phylum was the Bacillariophyta that was poorly recorded inside and at the entrance of the cave $(<0.7 \%)$. On the contrary, outside the cave they were represented by $6.5 \%$ of the total eukaryotes sequenced. Our results have also showed high proportion of unclassified eukaryotes (32.7\%) inside the cave. Finally, Streptophyta were represented in all biofilm samples. However, it is necessary to consider that bryophytes are multicellular organisms and thus can deeply prevaricate semi-quantitative information provided by the sequencing.

The proportion of cyanobacteria populating the bottom of the cave highlighted an important proportion of Nostocales (98\%). At the entrance and outside the cave, high proportion of undefined cyanobacteria ( $84.2 \%$ and $47.8 \%$, respectively) were recorded. Outside the cave, excluding the undefined cyanobacteria, the most represented cyanobacteria were Synechococcales (28.6\%), Nostocales (14.3\%) and Chroococcidiopsidales (6.6\%).

\subsubsection{Influence of biofilm localization}

Richness of phototrophic organisms significantly decreased from the outside to the inside of the cave ( $p$ value $<0.001$ ) (Fig. 3a). Bacterial richness showed the same decreasing trend, but no significant difference was obtained between the outside and the entrance of the cave (Fig. 3b). The Simpson indices for phototrophs and bacteria also showed a similar trend. However, the index for phototrophs showed significant difference $(p$-value $<0.001)$ only for the outside samples, whereas the index for bacteria showed no significant difference between the three areas (Fig. 3c, 3d). On the contrary, Simpson evenness for phototrophic organisms was significantly lower at the entrance than the others ( $p$-value< 0.01) (Fig. 3e). No significant difference of Simpson evenness for bacteria was observed (Fig. 3f).

\subsubsection{Composition of the bacterial and phototrophic communities}

Phototrophic communities were different among the outside, the entrance and the inside of the cave, although the communities at the entrance and the outside were more similar in comparison with these at the inside (Fig. 4a). On the other hand, a greater variability of the phototrophic organisms was observed at the inside of the cave. In the same way, the samples from entrance have a sparser distribution in comparison to outside communities. These samples were scraped on blue biofilms (Fig. 1a), while the others on green spots.

As well as the eukaryotic phototroph communities (Chlorophyta, Bacillariophyta and Streptophyta), the prokaryotes showed the same trend (Fig. 4b). On this regard, three types of prokaryote communities were more distinguished than phototrophic communities. Moreover, biofilms at outside could be divided into two groups. The first group corresponded to biofilms scraped from the soil, while the second group was sampled on limestone rocks. 


\subsubsection{Comparison of organism communities}

Phototroph organisms encompassed 154 OTUs, while 3,872 bacterial OTUs were recorded. The obtained phototroph OTUs, which were recorded only on one specific area, represented $<4 \%$ of the total DNA reads, while OTUs shared at least in two cave sections represented 3.6\%. Moreover, 23 OTUs are shared by samples from outside the cave, at the entrance and inside. They were represented by $92.5 \%$ of the total reads. These OTUs were composed by 10 chlorophytes, 9 cyanobacteria, two unclassified eukaryotes, one bacillariophyte and one streptophyta (Fig. 5a).

The Venn diagram, obtained from bacteria data (Fig. 5b), has shown that 419 OTUs (corresponding to $14.6 \%$ of all the OTUs) were shared by the three sampled cave areas. However, they corresponded to $56.2 \%$ of the total bacterial reads. Thus, our results have indicated that 1,597 OTUs $(55.6 \%$ of all the OTUs) were specific to one of the three sampled sites. Nevertheless, these OTUs were only representing $9.7 \%$ of total reads.

\section{Discussion}

In the present study, we have compared both bacterial and phototrophic communities inhibiting (i) the cave area illuminated by artificial light, (ii) the entrance, characterized by low natural light intensity, and (iii) the outside of the cavity, irradiated by high intensity of natural light.

\section{Biofilm community diversity}

Both the studied Eukaryote and Prokaryote microorganisms have showed a richness decrease from the outside to the bottom of the Azé cave. The obtained results in Azé are not surprising considering that the outside part of the cave is bordered by the forest and that the 60th first meters of the cave are strongly influenced by the outdoor parameters [41]. From the 60th meter to the bottom of the cave, environmental conditions are relatively stable and thus less influenced by the outside, which explain the lowest richness of bacteria and photosynthetic organisms. The microorganism richness decrease was already reported by Roldán et al. (2004) [47], Piano et al. (2015) [48] and Abris et al. (2020) [49] for the phototrophs and fungal propagules, respectively. The authors have described a negative correlation between distance from the cave entrance and propagule deposition rate. This is explained by the gradual reduction of the air currents that spread microorganisms from the entrance to the bottom of the cave [50]. In the case of Azé, the touristic activity factor also plays a role, but it is probably limited to the artificial lighting that allows the growth of phototrophs and the resulting development of bacteria. Moreover, insects and animals may probably play a more important role in the microorganism cave spreading in comparison to the touristic activity [28]. However, further studies should be implemented for a better understanding of the influence of insect and animal in the spread of cave microorganisms. In fact, our data have shown that only four OTUs, corresponding to rare OTUs and $<0.1 \%$ of the total reads, are specific to the cave inside. Moreover, the entrance data have showed the same trend. These results indicate that there is no specific 
phototrophic community inside the cave. However, the communities inhabiting the cavities may adapt to specific conditions such as low nutrient, temperature and light intensity [51].

\section{Communities change depending environmental factors}

In the Azé cave, the biofilm communities gathered several phototrophic phyla such as the well-known Chlorophyta, Cyanobacteria, Bacillariophyta and Streptophyta [4]. These phyla are frequently described by authors studying the cave microorganism proliferation $[17,52,53,54,55]$. However, the community distribution and abundance obtained in this study are not comparable to those previously published by other authors. More generally, there is often variation from one study to another. This observation may be due to many environmental factors (i.e., temperature, moisture, nature of the substrata, light intensity). In fact, even if the Chlorophyta phylum was dominant everywhere in the Azé cave, the proportion of Chlorophyta, Bacillariophyta, Stretophyta and Unclassified Eukaryota varied depending on the location they were sampled. This finding was more obvious concerning the Cyanobacteria order with $98.1 \%$ of Nostocales inside the cave and less than $14.4 \%$ in the entrance and outside the cave. However, these results are consistent with Budzyńska et al. (2019) [56], reporting that the Nostocales proliferation is dependent of low light. Bacillariophyta were mainly recorded outside the cave (6\%) and poorly in the entrance or inside the cave $(>0.7 \%)$. This low proportion may be explained by the fact that Bacillariophyta are not considered as primary colonizers in opposition to Chlorophyta and Cyanobacteria [28]. In fact, outside biofilms are several years old and thus mature, in opposition to cave biofilms that are regularly treated by the curators. Moreover, it was reported that wet [4] and illuminated surfaces [20], such as in the outside the Azé cave, are the main factors for Bacillariophyta development.

\section{Conclusion}

Our results have highlighted that caves are colonized by a high diversity of bacterial community depending on the substrata and the environmental conditions. Comparing to the outside of the cave, these communities seem specific to the inside. Since artificial lights were used for touristic purpose, the Azé cave ecosystem has been modified leading to new development of phototrophs. In the present study, we have demonstrated that these communities are not significantly different from the cave outside phototrophs. The main differences consist on a richness decrease from the outside to the bottom of the cave, explained by the decreasing influence of the cave outside environment. It is noteworthily to highlight the difference of communities from one biofilm to another inside the cave; these differences may be linked to the community functional traits, especially the limestone biodeterioration processes. Finally, further studies should examine how the substratum physico-chemical parameters influence the biofilm community proliferation.

\section{Declarations}

\section{Acknowledgement}


First of all, we are grateful to the curators of the Azé Cave, who kindly gave us permission to access the cave and to carry out all our field experiments. We also thank the Ministère de la Culture et de la Communication (France), the Laboratoire de Recherche des Monuments Historiques (LRMH, Paris) and l'Association Culturelle du Site d'Azé for their financial contribution.

\section{- Funding}

The Ministère de la Culture et de la Communication (France), the Laboratoire de Recherche des Monuments Historiques (LRMH, Paris) and l'Association Culturelle du Site d'Azé have funded the research.

\section{- Conflicts of interest/Competing interests}

The authors declare that they have no known competing financial interests or personal relationships that could have appeared to influence the work reported in this paper.

\section{- Availability of data and material}

Sequencing data were deposited in the GenBank database under the BioProject ID: PRJNA723481.

\section{- Software application or custom code}

Not applicable.

\section{- Authors' contributions}

Badr Alaoui-Sosse: Writing - original draft. Shinji Osaki: Data curation, Formal analysis, Software, Visualization. Lionel Barriquand: Conceptualization, Validation, Writing - review \& editing. Daniele De Luca: Software, Software, Visualization. Paola Cennamo: Software, Writing - original draft. Benoit Valot: Software, Writing - original draft. Laurence Alaoui-Sosse: Data curation. Pascale Bourgeade: Software, Writing - review \& editing. Faisl Bousta: Writing - original draft. Lotfi Aleya: Validation, Writing - review \& editing. Stéphane Pfendler: Conceptualization, Validation, Visualization, Writing - original draft, Writing review \& editing.

\section{References}

1. Tomczyk-Żak K, Zielenkiewicz U (2015) Microbial diversity in caves. Geomicrobiol J 33:20-38

2. Brar AK, Bergmann D (2019) Culture-based analysis of 'Cave Silver' biofilms on Rocks in the former Homestake mine in South Dakota, USA. Int J Speleol 48:145-154

3. Barton HA, Jurado V (2007) What's Up Down There? Microbial Diversity in Caves Microorganisms in caves survive under nutrient-poor conditions and are metabolically versatile and unexpectedly diverse Microbe (Washington, D.C.) American Society for Microbiology Microbe 2:132-138 
4. Falasco E, Ector L, Isaia M, Wetzel CE, Hoffmann L, Bona F (2014) Diatom flora in subterranean ecosystems: a review. Int J Speleol 43:231-251

5. Roldán M, Hernández-Mariné M (2009) Exploring the secrets of the three-dimensional architecture of phototrophic biofilms in caves. Int J Speleol 38:41-53

6. Pfendler S, Karimi B, Maron PA, Valot B, Bousta F, Alaoui-Sosse L, Alaoui-Sossé B, Aleya L (2018) Biofilm biodiversity in French and Swiss show caves using the metabarcoding approach: First data. Sci Tot Env 615:1207-1217

7. Porca E, Jurado V, Žgur-Bertok D, Saiz-Jimenez C, Pašić L (2012) Comparative analysis of yellow microbial communities growing on the walls of geographically distinct caves indicates a common core of microorganisms involved in their formation. FEMS Microbiol Ecol 81:255-266

8. Baquedano Estévez C, Moreno Merino L, de la Losa Román A, Durán Valsero JJ (2019) The lampenflora in show caves and its treatment: an emerging ecological problem. Int J Speleol 48:249277

9. Del Mondo A, Pinto G, Allegra Carbone D, Pollio A, De Natale A (2018) Biofilm architecture on different substrates of an Oculatella subterranea (Cyanobacteria) strain isolated from Pompeii archaeological site (Italy). Environ Sci Pollut Res 25:26079-26089

10. Jones AA, Bennett PC (2017) Mineral Ecology: Surface Specific Colonization and Geochemical Drivers of Biofilm Accumulation, Composition, and Phylogeny. Front Microbiol 8:491

11. Popović S, Subakov Simić G, Stupar M, Unković N, Krunić O, Savić N, Ljaljević Grbić M (2017) Cave biofilms: characterization of phototrophic cyanobacteria and algae and chemotrophic fungi from three caves in Serbia. J Cave Karst Stud 79:10-23

12. Toyofuku M, Inaba T, Kiyokawa T, Obana N, Yawata Y, Nomura N (2016) Environmental factors that shape biofilm formation. Biosci biotechnol biochem 80:7-12

13. Stanley NR, Lazazzera BA (2004) Environmental signals and regulatory pathways that influence biofilm formation. Mol microbiol 52:917-924

14. Ghosh S, Kuisiene N, Cheeptham N (2016) The cave microbiome as a source for drug discovery: Reality or pipe dream? Biochem Pharmacol 134:18-34

15. Farmer JT, Shimkevitch AV, Reilly PS, Mlynek KD, Jensen KS, Callahan MT, Bushaw-Newton KL, Kaplan JB (2014) Environmental bacteria produce abundant and diverse antibiofilm compounds. J Appl Microbiol 117:1663-1673

16. Leplat J, François A, Touron S, Frouin M, Portais JC, Bousta F (2020) Aerobiological behavior of Paleolithic rock art sites in Dordogne (France): a comparative study in protected sites ranging from rock shelters to caves, with and without public access. Aerobiologia 1-20

17. Cennamo P, Montuori N, Trojsi G, Fatigati G, Moretti A (2016) Biofilms in churches built in grottoes. Sci Tot Env 543:727-738

18. Bastian F, Alabouvette C (2009) Lights and shadows on the conservation of a rock art cave: the case of Lascaux Cave. Int J Speleol 38:55-60 
19. Azúa-Bustos A, González-Silva C, Mancilla RA, Salas L, Palma RE, Wynne JJ, McKay CP, Vicuña R (2009) Ancient photosynthetic eukaryote biofilms in an Atacama Desert coastal cave. Microb Ecol 58:485-496

20. Popović S, Nikolić N, Jovanović J, Predojević D, Trbojević I, Manić L, Subakov Simić G (2019) Cyanobacterial and algal abundance and biomass in cave biofilms and relation to environmental and biofilm parameters. Int J Speleol 48:49-61

21. Hodač L, Brinkmann N, Mohr KI, Arp G, Hallmann C, Ramm J, Spitzer K, Friedl T (2015) Diversity of Microscopic Green Algae (Chlorophyta) in Calcifying Biofilms of Two Karstic Streams in Germany. Geomicrobiol J 32:3-4

22. Borsodi AK, Knáb M, Krett G, Makk J, Márialigeti K, Erőss A, Mádl-Szőnyi J (2012) Biofilm Bacterial Communities Inhabiting the Cave Walls of the Buda Thermal Karst System, Hungary. Geomicrobiol J 29:611-627

23. Borsodi AK, Anda D, Makk J, Krett G, Dobosy P, Büki G, Erőss A, Mádl-Szőnyi J (2018) Biofilm forming bacteria and archaea in thermal karst springs of Gellért Hill discharge area (Hungary). J Basic Microbiol 58:928-937

24. Zammit G, Billi D, ShuBert E, Kaštovský J, Albertano P (2011) The biodiversity of subaerophytic phototrophic biofilms from Maltese hypogea. Fottea 11:187-201

25. Anda D, Krett G, Makk J, Márialigeti K, Mádl-Szőnyi J, Borsodi AK (2017) Comparison of bacterial and archaeal communities from different habitats of the hypogenic Molnár János Cave of the Buda Thermal Karst System (Hungary). J Caves Karst Stud 79:113-121

26. D'Auria G, Artacho A, Rojas RA, Bautista JS, Méndez R, Gamboa MT, Gamboa JR, Gómez-Cruz R (2018) Metagenomics of Bacterial Diversity in Villa Luz Caves with Sulfur Water Springs. Genes 9:55

27. Cailhol D, Ciadamidaro L, Dupuy D, Allegra S, Girardot F, Pfendler S (2020) Fungal and bacterial outbreak in the wine vinification area in the Saint-Marcel show cave. Sci Tot Env 733:138756

28. Jurado V, del Rosal Y, Gonzalez-Pimentel JL, Hermosin B, Saiz-Jimenez C (2020) Biological control of phototrophic biofilms in a show cave: The case of Nerja Cave. Appl Sci 10:10-3448

29. Arp G, Bissett A, Brinkmann N, Cousin S, De Beer D, Friedl T, Mohr KI, Neu TR, Reimer A, Shiraishi F, Stackebrandt E, Zippel B (2010) Tufa-forming biofilms of German karstwater streams: microorganisms, exopolymers, hydrochemistry and calcification. Geological Society, London, Special Publications, 336: 83-118

30. Baskar S, Baskar R, Routh J (2011) Biogenic Evidences of Moonmilk Deposition in the Mawmluh Cave, Meghalaya, India. Geomicrobiol J 28:252-265

31. Albertano P (2012) In: Whitton BA (ed) Cyanobacterial Biofilms in monuments and Caves, Ecology of Cyanobacteria II: Their Diversity in Space and Time. Springer Science, Business Media, pp 317-344

32. Banerjee S, Joshi SR (2016) Culturable bacteria associated with the caves of Meghalaya in India contribute to speleogenesis. J Caves Karst Stud 78:144-157

33. Steinhauer ES, Omelon CR, Bennett PC (2010) Limestone Corrosion by Neutrophilic Sulfur-Oxidizing Bacteria: A Coupled Microbe-Mineral System. Geomicrobiol J 27:723-738 
34. Adhikary SP, Keshari N, Urzì C (2015) Cyanobacteria in biofilms on stone temples of Bhubaneswar, Eastern India. Algo Stud 147:67-93

35. Ciferri O (1999) Microbial Degradation of Paintings. Appl Environ Microb 65:879-885

36. Cutler N, Oliver AE, Viles H, Ahmad S, Whiteley AS (2013) The characterisation of eukaryotic microbial communities on sandstone buildings in Belfast, UK, using TRFLP and 454 pyrosequencing. Int Biodeter Biodegr 82:124-133

37. Nugari MP, Pietrini AM, Caneva G, Imperi F, Visca P (2009) Biodeterioration of mural paintings in a rocky habitat: The Crypt of the Original Sin (Matera, Italy). Int Biodeterior Biodegrad 63:705-711

38. Morse KV, Richardson DR, Brown TL, Vangundy RD, Cahoon AB (2021) Longitudinal metabarcode analysis of karst bacterioplankton microbiomes provide evidence of epikarst to cave transport and community succession. Peer J 9:10757

39. Thompson B, Richardson D, Vangundy RD, Cahoon AB (2019) Metabarcoding comparison of prokaryotic microbiomes from appalachian karst caves to surface soils in southwest Virginia, USA. $J$ Cave Karst Stud 81:4

40. Nikolić N, Zarubica N, Gavrilović B, Predojević D, Trbojević I, Subakov Simić G, Popović S (2020) Lampenflora and the entrance biofilm in two show caves: comparison of microbial community, environmental, and biofilm parameters. J Cave Karst Stud 82:69-81

41. Barriquand L, Barriquand J, Argant A, Floss H, Gallay A, Guérin C, Guillot L, Jeannet M, Nykiel C, Quinif Y (2011) Le site des grottes d'Azé. Quaternaire 4:15-25

42. Barriquand J, Barriquand L, Guillot L, Nykiel C (2011b) Le site des grottes d'Azé, le fruit de 60 ans de recherches dans le karst du massif de Rochebin (Saône-et-Loire). Spelunca 59:19-32

43. Pfendler S, Einhorn O, Karimi B, Bousta F, Cailhol D, Alaoui-Sosse L, Alaoui-Sosse B, Aleya L (2017) UV-C as an efficient means to combat biofilm formation in show caves: evidence from the La Glacière Cave (France) and laboratory experiments. Environ Sci Pollut Res 24:24611-24623

44. Sherwood AR, Presting GG (2007) Universal primers amplify a 23S rDNA plastid marker in eukaryotic algae and cyanobacteria. J Phycol 43:605-608

45. Marcelino VR, Verbruggen H (2016) Multi-marker metabarcoding of coral skeletons reveals a rich microbiome and diverse evolutionary origins of endolithic algae. Sci Rep 6:31508

46. Schloss PD, Westcott SL, Ryabin T, Hall JR, Hartmann M, Hollister EB, Lesniewski RA, Oakley BB, Parks DH, Robinson CJ, Sahl JW, Stres B, Thallinger GG, Horn DJ, Van Weber CF (2009) Introducing mothur: open-source, platform-independent, community-supported software for describing and comparing microbial communities. Appl Environ Microbiol 75:7537-7541

47. Roldán M, Clavero E, Canals T, Gómez-Bolea A, Ariño X, Hernández-Mariné M (2004) Distribution of phototrophic biofilms in cavities (Garraf, Spain). Nova Hedwigia 78:329-351

48. Piano E, Bona F, Falasco E, La Morgia V, Badino G, Isaia M (2015) Environmental drivers of phototrophic biofilms in an Alpine show cave (SW-Italian Alps). Sci Total Environ 536:1007-1018 
49. Abris MI, Palanca MG, De Leon MP, Banaay CGB (2020) Microbial air and water quality assessment of a freshwater limestone cave in the philippines and its implications for ecotourism management. JNS 19:33-48

50. Mulec J, Vaupotič J, Walochnik J (2012) Prokaryotic and Eukaryotic Airborne Microorganisms as Tracers of Microclimatic Changes in the Underground (Postojna Cave, Slovenia). Microb Ecol 64:654-667

51. Mulec J (2008) Microorganisms in hypogeon: Examples from Slovenian karst caves 37:153-160

52. Smith T, Olson R (2007) A taxonomic survey of lamp flora (algae and cyanobacteria) in electrically lit passages within Mammoth Cave National Park, Kentucky. Int J Speleol 36:105-114

53. Urzì C, De Leo F, Bruno L, Albertano P (2010) Microbial Diversity in Paleolithic Caves: A Study Case on the Phototrophic Biofilms of the Cave of Bats (Zuheros, Spain). Microb Ecol 60:116-129

54. Cennamo P, Marzano C, Ciniglia C, Pinto G, Cappelletti P, Caputo P, Studies K (2012) A survey of the algal flora of anthropogenic caves of Campi Flegrei (Naples, Italy) archeological district. J Cave Karst Stud 74:243-250

55. Borderie F, Denis M, Barani A, Alaoui-Sossé B, Aleya L (2016) Microbial composition and ecological features of phototrophic biofilms proliferating in the Moidons Caves (France): investigation at the single-cell level. Environ Sci Pollut Res 23:12039-12049

56. Budzyńska A, Rosińska J, Pełechata A, Toporowska M, Napiórkowska-Krzebietke A, Kozak A, Messyasz B, Pęczuła W, Kokociński M, Szeląg-Wasielewska E, Grabowska M, Mądrecka B, Niedźwiecki M, Alcaraz Parraga P, Pełechaty M, Karpowicz M, Pawlik-Skowrońska B (2019) Environmental factors driving the occurrence of the invasive cyanobacterium Sphaerospermopsis aphanizomenoides (Nostocales) in temperate lakes. Sci Tot Env 650:1338-1347

\section{Figures}




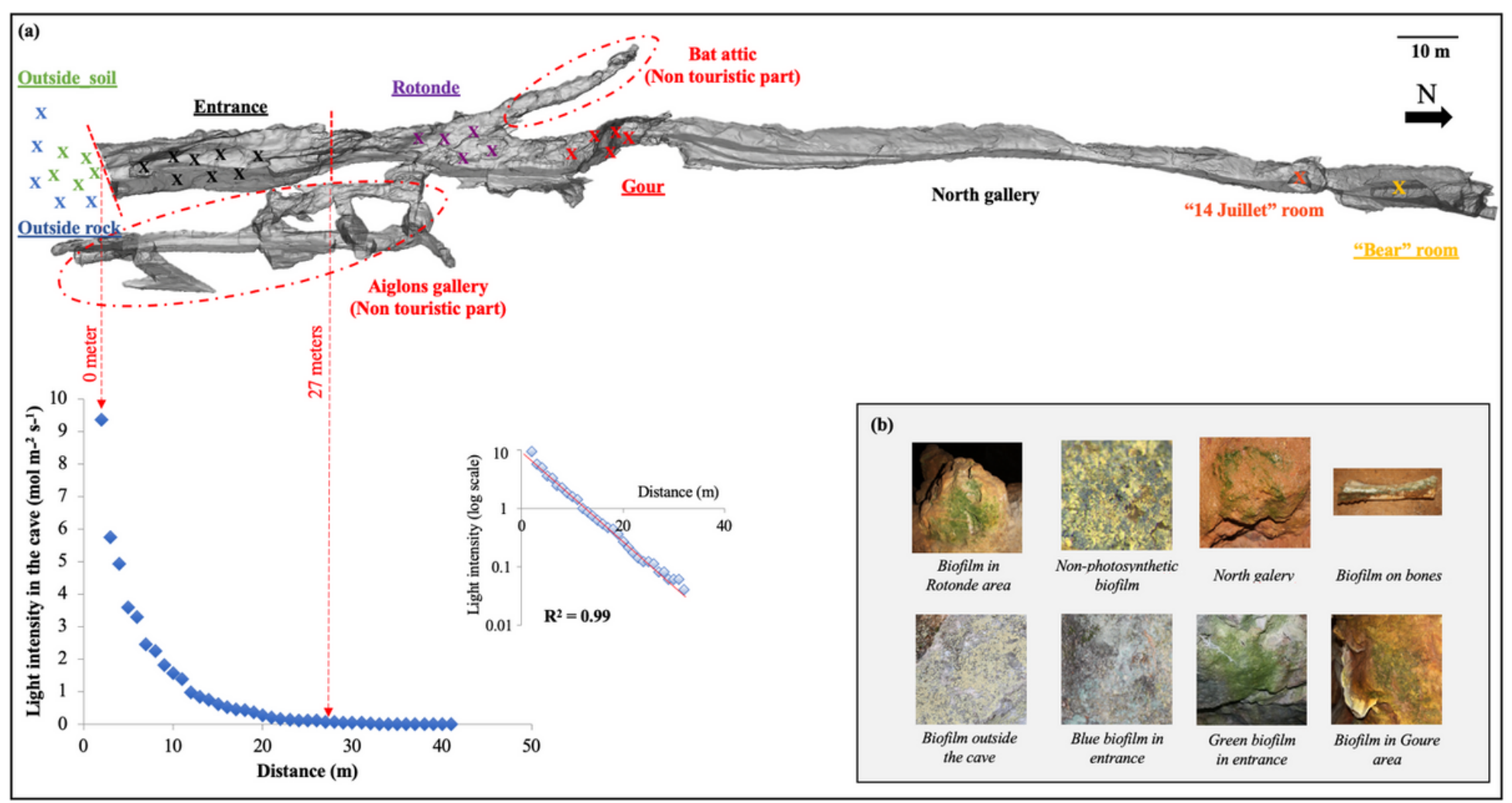

\section{Figure 1}

(a) The natural light profile was measured in the Azé cave. The colored crosses on the three-dimensional plan indicate the location of the sampled biofilms (b).

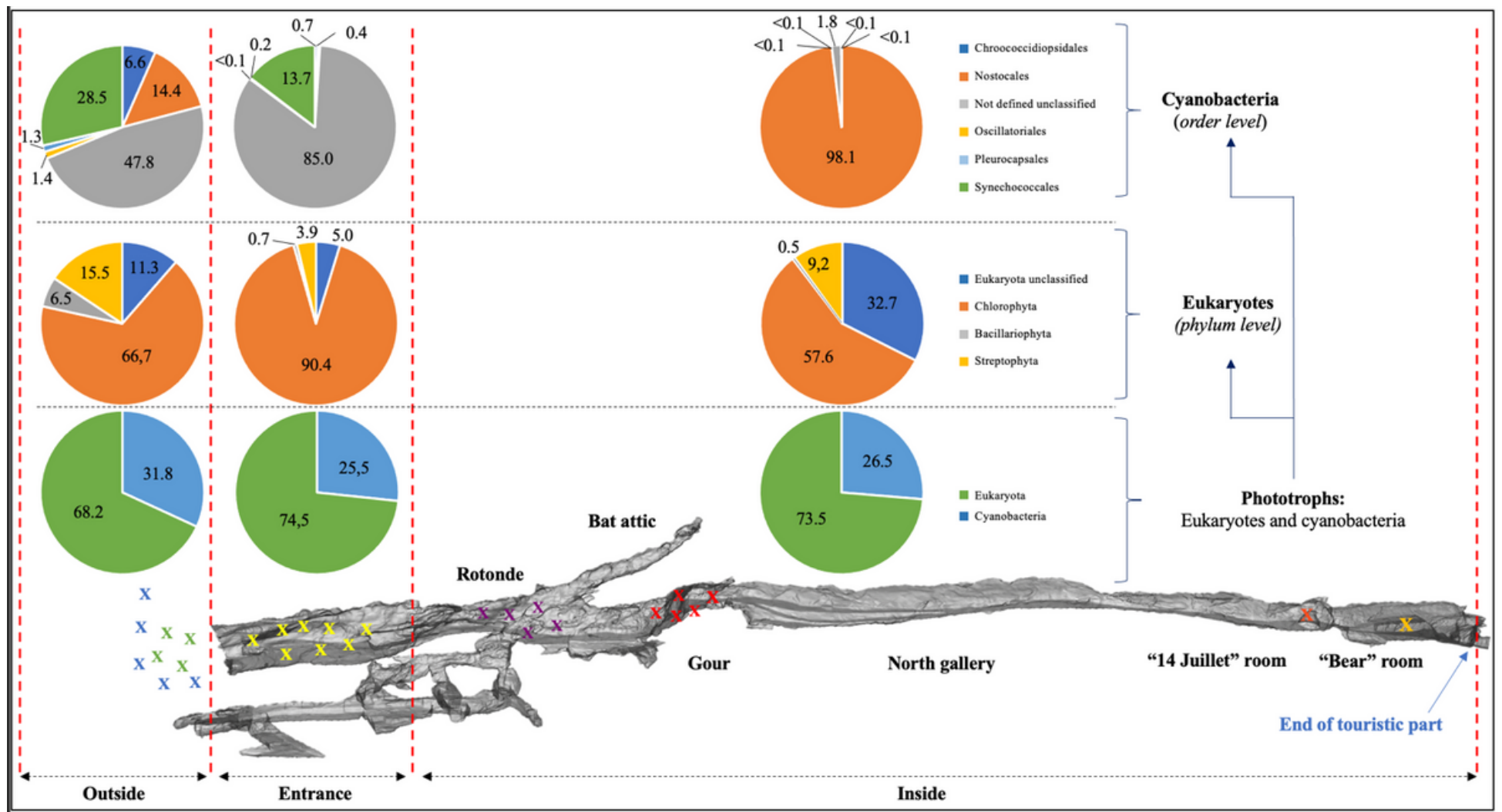

Figure 2 
Distribution of the photosynthetic organisms according to their sampling localization (outside, entrance or inside the cave).

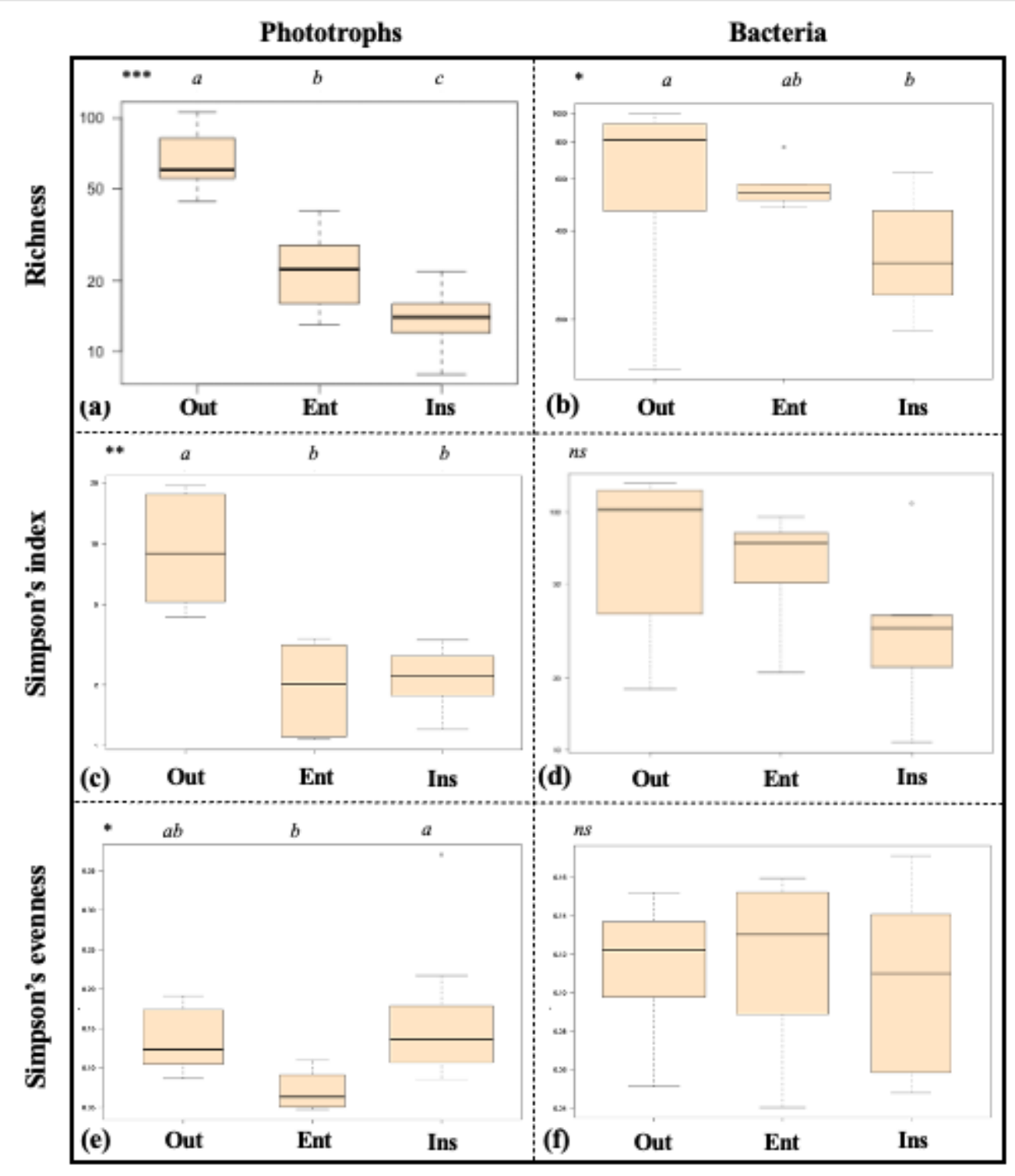

Figure 3

The richness, and both Simpson index and evenness indices of bacteria and phototrophic organisms were calculated (Out = outside, Ent $=$ entrance, Ins = inside; results of the statistical analyses are represented by the letters $\mathrm{a}, \mathrm{b}, \mathrm{c}, \mathrm{ns}$ and $*, * *$ or $* \star *)$. 

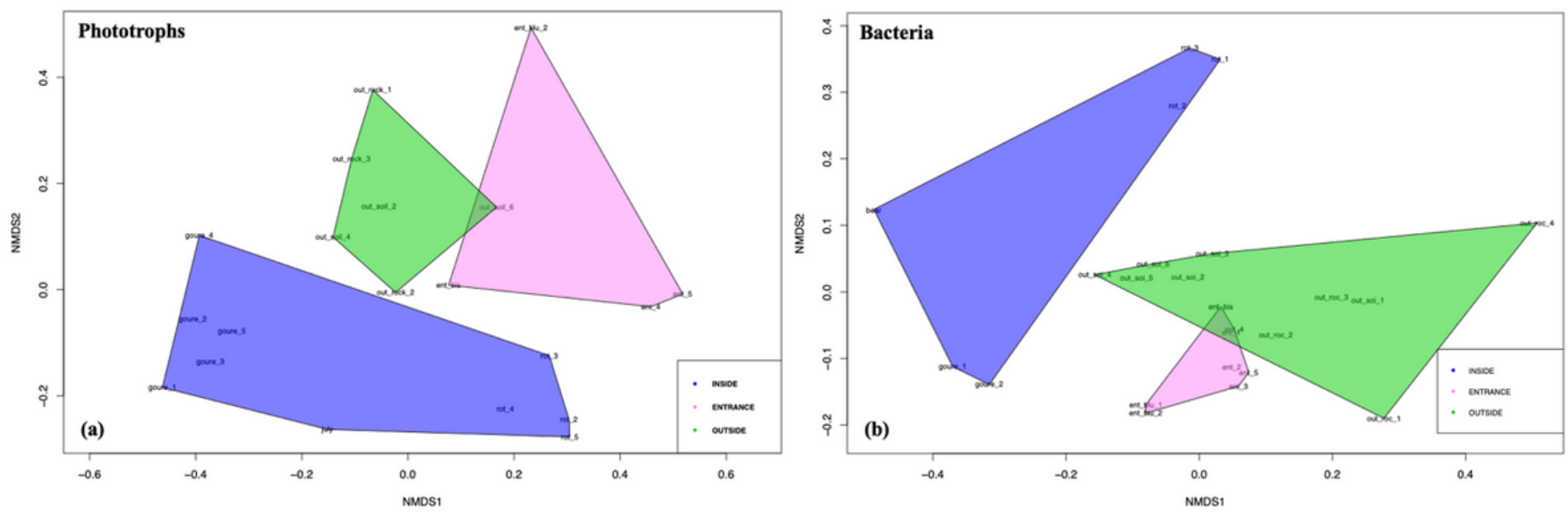

Figure 4

Non-metric multidimensional scaling of (a) phototrophs and (b) bacterial communities in the three sampled area of the show caves.

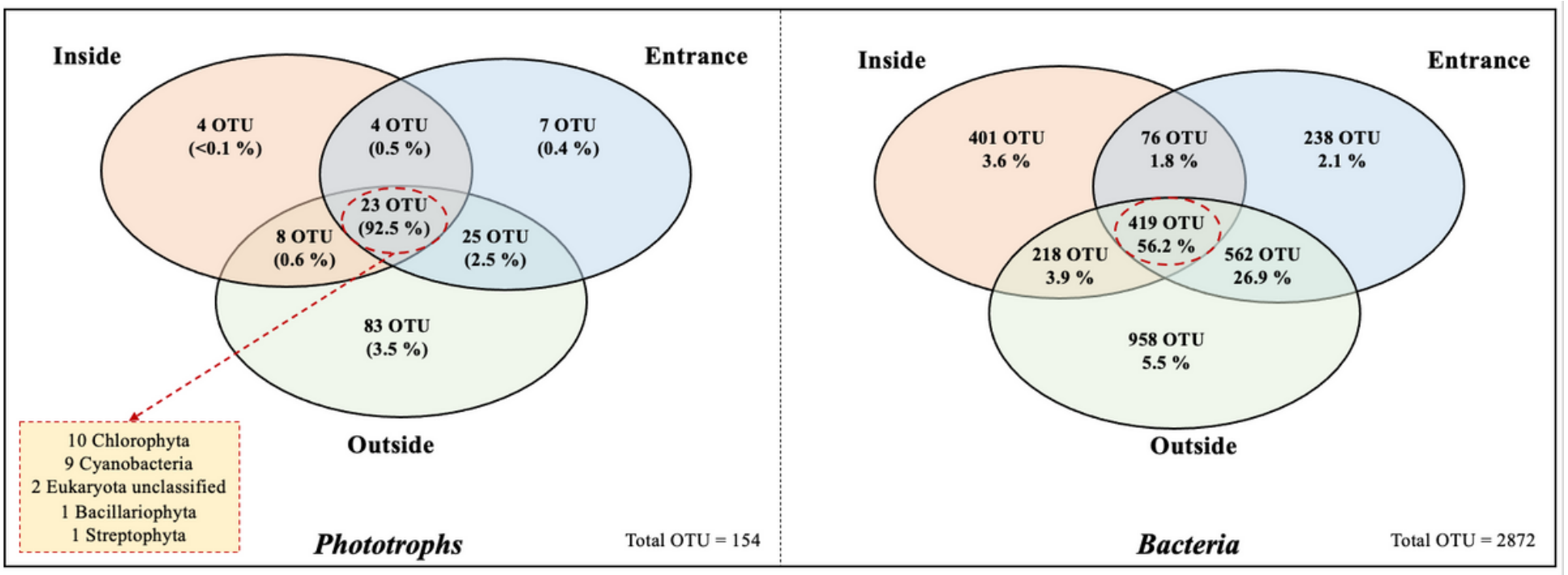

Figure 5

Comparison of organism communities in the Azé cave using Venn diagram.

\section{Supplementary Files}

This is a list of supplementary files associated with this preprint. Click to download.

- PubAzeSup.docx 